7. Терно С. О. Критичне мислення - сучасний вимір суспільствознавчої освіти / С. О. Терно. - Запоріжжя : Просвіта, 2009. - 268 с. 8. Тягло О. В. Критичне мислення: [навч. посіб.] / О. В Тягло. - Х. : Основа, Вип. 1(61). - 2008 - 192 с. 9. Халперн Д. Психология критического мышления / Д. Халперн. - СПб. : Питер, 2000. - 512 с. 10. Хачумян Т. І. Поняття «критичне мислення» та його сутність в психолого-педагогічній науці / Т. І. Хачумян // Теоретичні питання культури, освіти та виховання : [3б. наук. пр.] - Вип. 24. -Ч. 2. - К. : Вид. центр КНЛУ, 2003. - С. 171-177.

УДК 738:37.011.3-051:005.336.5

Інна Талащ

\title{
РОЗВИТОК ЗДАТНОСТІ ДО ПЕДАГОГІЧНОЇ ТВОРЧОСТІ МАЙБУТНІХ УЧИТЕЛІВ ПОЧАТКОВИХ КЛАСІВ
}

Талаш І. О. Розвиток здатності до педагогічної творчості майбутніх учителів початкових класів.

У статті зроблено спробу проаналізувати етапи розвитку здатності майбутніх учителів до педагогічної творчості, з'ясувати чинники, що впливають на розвиток творчої особистості студентів педагогічних факультетів, виявити потенційні можливості інноваційних педагогічних технологій у процесі становлення особистості майбутнього професіонала.

Ключові слова: творчість, педагогічна творчість, дивергентне мислення, інноваційні педагогічні технології, кредитно-модульна система навчання.

Талаш И. А. Развитие способности к педагогическому творчеству будущих учителей начальных классов.

В статье сделана попытка проанализировать этапы развития способности будущих учителей к педагогическому творчеству, выяснить факторы, влияющие на развитие творческой личности студентов педагогических факультетов, определить потенциальные возможности инновационных педагогических технологий в процессе становления личности будущего профессионала.

Ключевые слова: творчество, педагогическое творчество, дивергентное мышление, инновационные педагогические технологии, кредитно-модульная система обучения.

Talash I. A. Development of ability to pedagogical creativity of future elementary school teachers.

The article attempts to analyze the stages of development of the ability of future teachers for pedagogical creativity, find out the factors affecting the development of the creative personality of students of pedagogical faculties, identify potential innovative pedagogical technologies in the making of a future professional.

Key words: creativity, pedagogical creativity, divergent thinking, innovative educational technology, credit-modular system of training.

Сучасна початкова школа вимагає творчого вчителя, який вміє гнучко адаптуватися до інновацій і реформ, що впроваджуються в навчально-виховний процес, організовувати взаємодію з учнями на засадах особистісно зорієнтованого навчання. Важливість розв'язання означеної проблеми підкреслюється у державних програмах. Одним із стратегічних завдань, окреслених у Державній національній програмі «Освіта» («Україна XXI століття)), є створення умов для формування освіченої, творчої 
особистості громадянина, реалізації та самореалізації його природних задатків i можливостей в освітньому процесі. Висуваються завдання виховання нової генерації педагогічних кадрів, розроблення комплексу теоретичних і методичних основ щодо забезпечення підготовки вчителя до формування творчої особистості учня, скоординованої підготовки вчителів до ії формування в системі професійної освіти.

У світлі реформ системи освіти проблема формування творчої особистості $\epsilon$ актуальною, тому викликає інтерес з боку теоретиків і практиків різних галузей наукового знання, передусім педагогів і психологів. Психологічні аспекти творчості розкриті в працях Л. Виготського, В. Крутецького, О. Леонтьєва, О. Пономарьова, В. Рибалка, С. Рубінштейна та інших. Психолого-педагогічні проблеми формування творчої особистості висвітлено у працях таких дослідників, як: Б. Ананьєв, В. Андреєва, Г. Андерсен, Д. Богоявленська, С. Бондаренко, Р. Грановська, В. Загвязинський, А. Зак, В. Кан-Калик, А. Маслоу, А. Осборн, М. Поташник, К. Роджерс, В. Сухомлинський, Н. Тализіна, К. Тейлор, Е. Торренс та інших. Психолого-педагогічні чинники, що сприяють формуванню творчих здібностей особистості, мотиви тї творчої діяльності та розвиток творчої активності досліджувалися такими науковцями, як: І. Аверіна, Ю. Гільбух, О. Киричук, О. Матюшкін, В. Моляко, Б. Нікітін, М. Холодна, Г. Чистякова та інші.

Слід зазначити, що хоча теоретичні аспекти розвитку творчої особистості майбутнього вчителя досить грунтовно висвітлені в наукових працях, нині залишається недостатньо розробленим практичний аспект проблеми, а саме: визначення ефективних шляхів розвитку творчого потенціалу студентів у процесі вивчення ними дисциплін педагогічного циклу; вимагають уточнення психологопедагогічні умови розвитку педагогічної творчості майбутніх учителів.

Mema cmammi - 3'ясувати шляхи розвитку здатності до педагогічної творчості студентів педагогічних факультетів.

Активна творча діяльність учителя дає позитивний результат у тому випадку, коли грунтується на розвитку творчої активності студентів у ВНЗ і подальшій організації творчого пошуку вчителя у школі. Тому одним із завдань вишівської підготовки майбутніх учителів є розвиток їхніх творчих здібностей, нестандартного мислення, формування вмінь і навичок здійснювати в майбутньому навчально-виховний процес на творчому рівні. Разом із тим, дедалі частіше спостерігаються випадки, коли на семінарських і практичних заняттях студенти охоче відтворюють зміст конспектів, але виявляють пасивність, відчувають утруднення, коли викладач пропонує застосувати набуті знання в нових нестандартних умовах, тобто виявити здатність до педагогічної творчості. Складається враження, що студенти ніби чинять супротив, коли викладач намагається їх залучити до творчої діяльності, ніби їм не цікаві запропоновані завдання. Однак вони досить активні в навчальних ситуаціях, де треба діяти за аналогією. Аналізуючи спостереження за навчальною діяльністю студентів, ми припустили, що їх пасивність під час виконання творчих завдань зумовлена несформованістю (або недостатньою сформованістю) складників, що характеризують творчу особистість.

Психологи сутність творчої діяльності визначають як функціонування одного 3 аспектів інтелекту, як несвідомий процес, як одну зі стадій розв'язання задачі, як асоціативний процес і підкреслюють, що для творчості необхідний дивергентний стиль мислення (вперше описаний Дж. Гілфордом), для якого характерними є швидкість, оригінальність (здатність продукувати незвичні, віддалені асоціації), гнучкість (здатність виявити основні та нові властивості об'єкта і запропонувати нові способи їх використання) та складність (здатність продукувати різноманітні ідеї в нерегламентованій ситуації). 
Для підтвердження висунутих припущень ми запропонували студентам IV курсу спеціальності «Початкова освіта» виконати тести на визначення гнучкості мислення та словникового запасу, адже гнучкість $€$ однією з суттєвих ознак дивергентного мислення. Оскільки науково доведеним $є$ факт, що мислення та мовлення взаємопов'язані й взаємозумовлені, то зіставлення результатів двох тестових методик дозволить більш глибоко з'ясувати характер взаємозв'язку між особливостями мовленнєвої діяльності студентів і ригідністю їх мислення.

Для визначення ригідності словникового запасу студентів використана методика TTR. Студентам запропоновано написати твір на тему «Учитель». Аналіз студентських робіт проводився у двох напрямках: спочатку рахували загальну кількість слів у творі, а потім - кількість слів, що було вжито лише один раз. Після цього визначали ригідність словникового запасу (вокабулятора) студентів, тобто встановлювали індекс вокабулярної ригідності (ВР) за такою формулою: ВР = P/O, де $\mathrm{P}$ - кількість слів, ужитих один раз, О - загальна кількість слів.

За результатами дослідження студенти поділені на дві групи: флексибельні (якщо індекс вокабулярної ригідності становив 0,5 і менше) та ригідні (якщо індекс вокабулярної ригідності перевищував 0,5$)$. Аналіз робіт виявив, що переважна більшість четвертокурсників характеризується гнучкістю словникового запасу (таких виявилося 73,7\% від їх загальної кількості); ригідність виявили лише $26,3 \%$ студентів.

Зауважимо, що під час спостережень за усними відповідями на практичних заняттях, у процесі дискусій, усі без винятку студенти мали певні недоліки мовлення, а саме: вживання слів-паразитів (наприклад, «там», «ну», «е-е» тощо), русизмів (наприклад, «важність роботи» замість «важливість роботи»), кальок (наприклад, «приймають участь» тощо); або ж відповідь складалася з однотипних за своєю синтаксичною будовою речень. Деякі студенти, які за результатами методики TTR віднесені до групи ригідних, під час дискусій утруднюються добирати влучно слова, щоб висловити думку, чекають на допомогу викладача, підказок з аудиторії. Усі названі недоліки свідчать про ознаки ригідності мовлення. Це підтвердили й результати проведеного дослідження, адже навіть у флексибельній групі студентів індекс вокабулярної ригідності коливався в межах від 0,42 до 0,5 , і лише дві студентки мали показники 0,36 і 0,38 .

Для визначення особливостей вияву ригідності мислення була використана методика «Словесні лабіринти». Ми запропонували студентам знайти виходи із 10 словесних лабіринтів, витрачаючи на пошук кожного виходу не більше двох хвилин, і повідомили, що шлях до виходу із лабіринту вказує лише одне слово, яке починається в правому нижньому кутку (вхід до лабіринту) і закінчується в лівому верхньому кутку (вихід із лабіринту). Рухатися лабіринтом дозволяється лише від букви до букви по горизонталі або вертикалі в напрямку виходу із лабіринту. Забороняється рухатися по діагоналі, пропускати літери.

За результатами дослідження всі студенти поділені на дві групи: флексибільних (гнучких), які знаходять вихід з усіх 10 лабіринтів, і ригідних, які знаходять вихід із перших семи лабіринтів і не знаходять виходу із восьмого лабіринту. Подальші пошуки студентів (у лабіринтах 9 і 10) суттєво не впливають на оцінку. Слід зауважити, що результати цього дослідження суттєво відрізнялися від попереднього. Так, майже половина студентів $(42,1 \%)$, які виявили гнучкість словникового запасу, за результатами методики «Словесні лабіринти» були віднесені до групи осіб з ригідним мисленням. На нашу думку, такі результати можна пояснити тим, що реципієнти 
мають досить розвинений запас активної лексики, але не вміють швидко перебудовуватися в нових нестандартних ситуаціях, мислять стереотипно, мають набір стереотипних зразків поведінки, зокрема вербального реагування на ситуацію. Лише $31,6 \%$ студентів мали показники гнучкості мислення й мовлення за результатами обох методик, і 26,3\% - ригідності за обома методиками.

Аналіз результатів проведеного дослідження, спостереження за роботою студентів на семінарських і практичних заняттях дають змогу зробити висновок про те, що виконання творчих завдань вимагає значної пропедевтичної роботи зі студентами, спрямованої на розвиток дивергентного мислення, зокрема таких важливих його якісностей, як: самостійність (вмінням ставити нові завдання й розв'язувати їх), критичність (здатність не підпадати під уплив чужих думок, об'єктивно оцінювати позитивні та негативні аспекти явища або факту, виявляти цінне та помилкове в них), гнучкість (уміння швидко змінювати свої дії при зміні ситуації діяльності, звільняючись від стереотипних способів і прийомів розв'язання аналогічних завдань), глибина (уміння проникати в сутність складних питань, розкривати причини явищ, бачити проблему там, де іiі не помічають інші, передбачати можливі наслідки подій і процесів), широта (здатність охопити широке коло питань, творче мислення в різних галузях знання та практики), послідовність (уміння дотримувати логічної наступності при висловлюванні суджень, їх обгрунтуванні), швидкість (здатність швидко зорієнтуватися в складній ситуації, швидко обдумати правильне рішення і прийняти його).

Переважна більшість сучасних педагогів уважають, що найбільш ефективним засобом розвитку складників дивергентного мислення є впровадження в навчальний процес освітніх закладів інноваційних педагогічних технологій. Зазначимо, що особливості кредитно-модульної системи, яка впроваджується в навчальний процес сучасних ВН3, дає широкі можливості викладачам у виборі технологій навчання, їх комбінуванні й використанні.

У розвитку здатності до педагогічної творчості майбутніх учителів ми виокремили такі етапи: подолання психологічної інертності, розвиток компонентів дивергентного мислення, залучення студентів до розв'язання творчих завдань з фахової підготовки.

Перше, із чим стикається викладач, коли пропонує студентам розв'язати творче завдання, - їх психологічна інертність, боязкість видатися некомпетентними 3 розглядуваного питання, припуститися помилки. Ефективним методом подолання психологічної інертності в педагогічній літературі визнано «Мозковий штурм», що використовується в інтерактивних технологіях навчання та в технологіях розвитку творчої особистості. Під час використання цього методу дозволяється висловлювати будь-які думки і припущення, при чому вони не критикуються учасниками навчального процесу. Однак і таке заохочення не завжди спрацьовує в студентській аудиторії, особливо на перших заняттях 3 певної дисципліни: натомість встановлюється вичікувальна мовчанка. Одним із можливих прийомів, що здатні активізувати студентів до вступу в діалог, є висунення самим викладачем низки гіпотез-запитань. Викладач сам починає пропонувати можливі відповіді на поставлене запитання. Спочатку питання формулюються прості, що не вимагають розгорнутої відповіді, поступово, коли аудиторія пожвавлюється, питання ускладнюються, спонукають студентів міркувати, висловлювати власні припущення. При цьому педагог стежить, щоб студенти дотримувалися основної вимоги: не може бути безглуздих припущень, відповідно, не можна коментувати відповіді інших вербальним чи невербальним способом. 
Досить перспективним, на наш погляд, $є$ використання кейс-технології в процесі вивчення педагогічних дисциплін, зокрема таких, як «Корекційна педагогіка», адже ця технологія, з одного боку, дозволяє заощадити навчальний час, відведений на аудиторні заняття, а 3 іншого боку, цілеспрямовано формувати компоненти дивергентного мислення студентів. При чому, кейс до дисципліни «Корекційна педагогіка» бажано складати на основі тих спостережень за учнем початкової школи, які відображені в щоденнику психолого-педагогічних спостережень, що заповнювали студенти під час виробничої практики на IV i V курсах. Відповідно, змістове наповнення кейсу в кожного студента своє, кожен складає програму педагогічної корекційної роботи для тієї дитини, із якою безпосередньо працював і спілкувався під час практики. Доцільність складання в такий спосіб кейсу зумовлена тим, що, по-перше, під час виробничої практики студенти заповнюють щоденник спостережень не формально, а цілеспрямовано, усвідомлюючи перспективу своєї дослідницької роботи, по-друге, формується внутрішня мотивація до складання програми педагогічної корекції, адже вони працюють не з узагальненим хрестоматійним прикладом, а $з$ ситуацією із реального життя, де $\epsilon$ можливість з'ясувати і максимально врахувати всі особливості й аспекти розвитку дитини, по-третє, створення цієї програми вимагає творчого підходу з боку студента. Загалом же робота над змістом кейсу вимагає від студента застосовувати набуті теоретичні знання творчо для розв'язання різноманітних (стандартних i нестандартних) ситуацій, що виникають у практиці початкової школи. Адже навіть аналогічні стандартні ситуації 3 позицій особистісно зорієнтованого підходу вимагають добору різних варіантів рішень, тому що змінні складники педагогічного процесу ніколи не можуть бути ідентичними, їх комбінації завжди унікальні, як унікальна сама особистість кожної дитини.

Отже, упровадження творчих завдань у навчальний процес вишу вимагає значної цілеспрямованої пропедевтичної роботи зі студентами із розвитку всіх компонентів дивергентного мислення. Одним із ефективних шляхів реалізації цього завдання $\epsilon$ використання інноваційних педагогічних технологій, які органічно поєднуються 3 кредитно-модульною системою навчання. У подальшому плануємо розробити методичні комплекси 3 використанням кейс-технології для вивчення дисципліни «Корекційна педагогіка».

\section{Література}

1. Богданова I. М. Педагогічні інновації в системі підготовки вчителя: кінець XX - початок XXI століття: [монографія] / Інна Михайлівна Богданова. - Одеса : М. П. Черкасов, 2009. - 157 с. 2. Гончаров С. М. Методи та технології навчання в кредитно-модульній системі організації навчального процесу : [навч.-метод. посіб.] / С. М. Гончаров, В. А. Гурин. - Рівне : НУВГП, 2010. - 451 с. 3. Гузій Н. В. Особистісно-орієнтовані технології дидаскалогічної підготовки майбутнього педагога : [метод. посіб.]/ Наталія Василівна Гузій. - К. : НПУ імені М. П. Драгоманова, 2007. - 45 с. 4. Загальна психологія: [підручник] / за ред. С. Д. Максименка - Вінниця : Нова Книга, 2004. - 704 с. 5. Мареева В. Модернизация высшего педагогического образования / В. Мареева, А. Данилюк // Педагогика. - 2007. - № 9. - С. 66-72. 6. Стрельніков В. Ю. Педагогічні основи забезпечення особистісного i професійного розвитку студентів засобами інноваційних технологій навчання / В. Ю. Стрельніков. - Полтава : РВВ ПУСКУ, 2002. -230 c. 